\title{
Genetic Diversity in Camptotheca Decaisne
}

\author{
Yujie Wang ${ }^{1}$, Beatrice Clack $^{2}$ and Shiyou $\mathrm{Li}^{1{ }^{1, *}}$
}

${ }^{I}$ National Center for Pharmaceutical Crops, Arthur Temple College of Forestry and Agriculture, Stephen F. Austin State
University, Nacogdoches, TX 75962, USA; ${ }^{2}$ Division of Biotechnology, Science Research Center, College of Sciences
and Mathematics, Stephen F. Austin State University, Nacogdoches, TX 75962, USA

\begin{abstract}
RAPD markers were used to reveal the genetic diversity of the genus Camptotheca. Three primers (OPA02, OPA03, and OPA04), generating 44 polymorphic bands using randomly amplified polymorphic DNA (RAPD) markers, were able to discriminate among 25 Camptotheca populations. The band size varied from $268-4,411 \mathrm{bp}$, with an average of 15 bands/primer. Of these populations, cultivars 'Katie' (KT) and 'Ang' (AG) of C. lowreyana and cultivated A1a (HJ) of C. acuminata can be easily distinguished by their unique bands. Population differentiation of Camptotheca was found to be higher than in other species with similar breeding systems. Cluster analysis of the genetic distance values and dendrogram from RAPD markers were consistent with the phenotypic data and both support the current taxonomic treatment of Camptotheca. Camptotheca acuminata var. acuminata appeared as the closest relative of C. yunnanensis, followed at some distance by C. lowreyana and, further away, C. acuminata var. tenuifolia.
\end{abstract}

Keywords: Camptotheca, dendrogram, genetic diversity, Nei's genetic distance, populations, randomly amplified polymorphic DNA (RAPD) markers.

\section{INTRODUCTION}

Camptotheca trees grow fast and many parts of the trees can be used to extract drug camptothecins (CPTs) [1]. However, there are several major problems with the development of Camptotheca as a drug resource. First, the genus is in endangered status in its natural range and may be nearing extinction in the immediate future. Second, the gene pool of Camptotheca in the USA is extremely small [2]. Selfing is often the only breeding system for these plants and the offspring are normally of low quality. Also, cold-hardiness and drought-tolerance are two major problems in plantation development in the southeastern USA. However, the present genetic resource base of Camptotheca in the USA is too small to select frost- and drought-tolerant and high-CPTyield genotypes.

Camptotheca is a Tertiary relict genus. Fossils of the genus were recorded in several locations in Japan from the Tertiary period [3, 4], and relatives of Camptotheca were recently reported in Paleocene floras of the Rocky Mountains and Great Plains in North America [5]. At present, the genus is naturally restricted to southern China. All three extant species of Camptotheca are in endangered status under natural conditions and may be nearing extinction in the immediate future [1].

Recently, there has been increasing interest in Camptotheca plantation development for CPT extraction in the United States, India, Japan, France, Germany, Australia, and Brazil. The lack of cold-hardiness and drought-tolerance are two main factors limiting the development of the plant

\footnotetext{
*Address correspondence to this author at the National Center for Pharmaceutical Crops, Arthur Temple College of Forestry and Agriculture, Stephen F. Austin State University, Nacogdoches, TX 75962, USA;

Tel: 936-468-2071; Fax: 936-468-7058; E-mail: lis@sfasu.edu
}

resources in these countries. However, the genetic base for plantation resources outside China is too narrow and small in number to allow selection of an ecotype for cold-tolerance, drought-resistance, or high biomass/drug production. In the United States, for example, C. acuminata was successfully introduced in 1934 and today has only about 20,000 seedlings largely in California, Hawaii, Louisiana, South Carolina, and Texas. However, most of these trees are traceable to two mature trees in Chico, California that germinated from seeds imported from southern China in 1934 (Fig. 1). Thus, relatedness is common within plantation populations due to this limited seed source. Selfing is often the only breeding system for these plants and the offspring are normally of low quality. Solutions to these genetic and adaptability problems are largely dependent on the expansion of the genetic base in China. However, to date little data are available on current resources in China. In fact, such a survey for Camptotheca does not exist.

Camptotheca is polygamo-monoecious. The stamens are shed nearly one week before the stigma of the same flower becomes receptive; this protandry leads to cross-pollination as the major breeding system in Camptotheca $[2,6]$. Pollination of Camptotheca is obligately entomophilous, and fruit production depends on the activities of pollinating insects [6]. It is relatively easy to reproduce seedlings by seed, a common propagation method in Camptotheca. Heating and stratification may increase the germination rates of seeds [7$10]$.

Camptotheca has great coppice ability and can be propagated vegetatively. Propagation by shoot and leaf cuttings has been studied at SFA and several other universities and nurseries. Micropropogation of C. acuminata by shoot bud, shoot tips, seed embryos, and cotyledon tissue culture has been studied at several universities [11, 12]. 


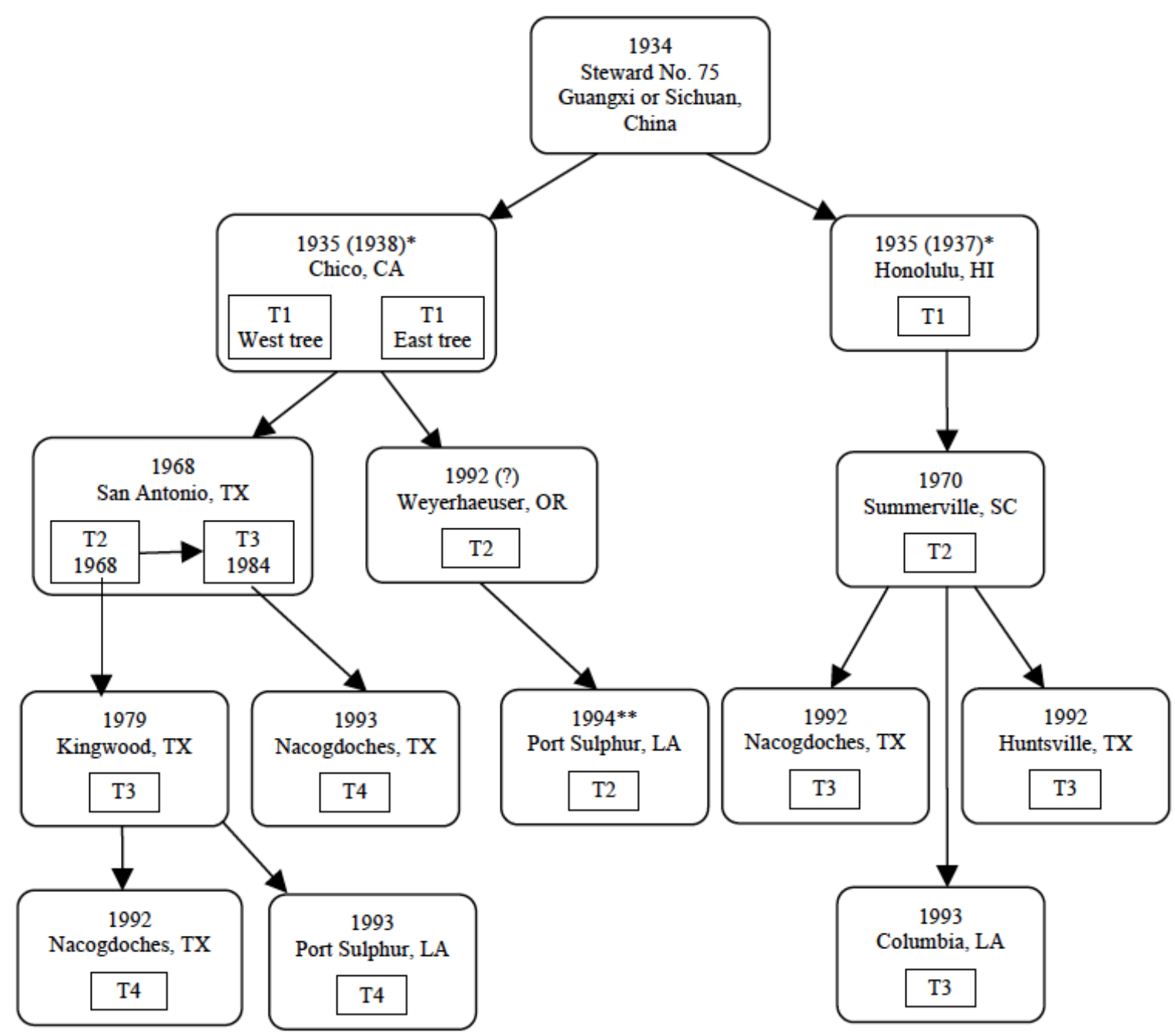

Fig. (1). Pedigree of principal seed sources of C. acuminata in the United States (The number following the letter "T" represents generation number of the trees; * seedlings were produced in 1935 and planted in 1937 or $1938 ; * *$ reproduced by tissue culture, others reproduced by seeds).

It is important to understand the genetic structure of a population or species for conservation and management strategies. Traditionally, genetic resources have been characterized by a combination of morphological and agronomic traits [13]. In forest management, provenance or geographical variation is often considered as an accurate predictor of the diversity spectrum within a species. This approach has been challenged by many recent studies [13]. Isozymes have been used extensively to monitor genetic diversity for plant species since the 1970s. Since the late 1980s, many authors have used restriction-site diversity to infer population genetic structure [14]. Restriction fragment length polymorphisms (RFLP) are the most frequently used type of DNA marker. RFLP analysis requires large quantities of relatively pure DNA and species-specific DNA probes, and is also labor intensive. Polymerase chain reaction (PCR) development revolutionized DNA analysis [15]. However, the PCR procedure requires DNA-sequence information.

A couple of decades ago, Williams et al., and Welsh and McClelland developed a novel RAPD (randomly amplified polymorphic DNA) technique for identification of polymorphism in plants based on PCR, which does not require prior
DNA sequence information $[16,17]$. This technique has provided a powerful tool for the investigation of genetic variation. The RAPD procedure is simpler and less costly than other DNA marker methodologies and requires very small amounts of DNA. RAPD markers have been successfully used in identification and classification of plants, e.g., crops [16, 18-21], ornamental species [22-26], rare species [27], forage species [28], and nitrogen-fixing species [29]. These studies have shown that inbred plants usually have extensive RAPD divergence among, but little variation within, species or populations. In contrast, outcrossing plants have considerable RAPD variation within species or populations [27, 28]. The RAPD markers will provide an important means to identify the species/clones of Camptotheca, particularly in the early stages of plant development, since it is difficult to distinguish the species/varieties prior to leaf formation.

\section{MATERIALS AND METHODS}

\section{Experimental Plants}

The experimental Camptotheca plants for DNA and CPT analysis, including 25 populations, were grown in 2 gallon pots in a greenhouse in Nacogdoches, Texas, USA (Table 1). 
Table 1. Description of the experimental plant materials.

\begin{tabular}{|c|c|c|c|}
\hline \multicolumn{4}{|l|}{ C. acuminata var. acuminata } \\
\hline $\mathrm{GN}(=\mathrm{A} 2)$ & Guangdong, China & 1994 & 154 \\
\hline JT (=A4) & Sichuan, China & 1994 & 22 \\
\hline $\mathrm{ZJ}(=\mathrm{A} 7)$ & Zhejiang, China & 1994 & 220 \\
\hline $\mathrm{AH}(=\mathrm{A} 8)$ & Anhui, China & 1995 & 350 \\
\hline $\mathrm{SH}((=\mathrm{A} 5)$ & Unknown, China & 1994 & 20 \\
\hline $\mathrm{HG}(=\mathrm{B} 6 \mathrm{~b})$ & San Marino, CA, USA & 1995 & 134 \\
\hline $\mathrm{AT}(=\mathrm{B} 7 \mathrm{a})$ & Nacogdoches, TX, USA & 1996 & 36 \\
\hline $\mathrm{AB}(=\mathrm{B} 7 \mathrm{~b})$ & Nacogdoches, TX, USA & 1997 & 150 \\
\hline \multicolumn{4}{|l|}{ C. acuminata var. tenuifolia } \\
\hline G9 * & Guangdong, China & 1996 & 12 \\
\hline \multicolumn{4}{|l|}{ C. lowreyana var. lowreyana } \\
\hline LY $(=\mathrm{L} 2)^{*}$ & Guangdong, China & 1994 & 22 \\
\hline AG & Nacogdoches, TX, USA & 1997 & 8 \\
\hline \multicolumn{4}{|l|}{ C. lowreyana 'Hicksii' } \\
\hline HT & Nacogdoches, TX, USA & 1998 & 3 \\
\hline \multicolumn{4}{|l|}{ C. lowreyana 'Katie' } \\
\hline KT & Nacogdoches, TX, USA & 1995 & 120 \\
\hline \multicolumn{4}{|l|}{ C. yunnanensis } \\
\hline $\mathrm{KM}(=\mathrm{Y} 4)^{*}$ & Yunnan, China & 1996 & 11 \\
\hline $\mathrm{XB}(=\mathrm{Y} 1)$ & Yunnan, China & 1996 & 54 \\
\hline YB $(=Y 3)$ & Yunnan, China & 1994 & 20 \\
\hline
\end{tabular}

Notes: * Natural origin, and others cultivated.

The seeds were sown in peat pots (Metro-Mix 366 growing medium) for germination in March 1995, 1996, and 1997, respectively. Seedlings were transferred to two gallon polyethylene pots filled with soil mix (hardwood bark:vermiculite $=3: 1$ ) after one-month's growth. The day/night temperature regime was maintained at $35.0 / 23.9^{\circ} \mathrm{C}$ $\left(95 / 75^{\circ} \mathrm{F}\right)$ from March to November and $29.5 / 18.3^{\circ} \mathrm{C}$ $\left(85 / 65^{\circ} \mathrm{F}\right)$ from December to February. Plants were watered once a day during the growing season and once every two days during the winter. 


\section{Genetic Diversity}

The genomic DNA profiles were revealed by randomly amplified polymorphic DNA (RAPD) analysis [16]. The RAPD analysis was conducted according to variation of RAPD markers within and among species/populations of Camptotheca with three replications for each sample. All the markers were scored by presence vs. absence of a specific amplification.

Sample Preparation: Experimental materials for DNA analyses were randomly collected from each of five plants for each population in Table 1. Three fully unfolded leaves were collected from each of five plants per population on the same day. The leaf materials collected from the same plant were ground with liquid nitrogen and stored in the freezer at $-85^{\circ} \mathrm{C}$.

DNA Extraction: Total DNA was isolated from young leaves using the CTAB (hexadecyltrimethylammonium bromide) procedure described by Doyle and Doyle (1990) with modification [30]. $0.5 \mathrm{~g}$ of powder per sample was quickly placed into $25 \mathrm{~mL}$ of preheated CTAB buffer $\left(60^{\circ} \mathrm{C}\right)$ in a 50 $\mathrm{mL}$ falcon tube. The remaining leaf materials were returned to the freezer $\left(-70^{\circ} \mathrm{C}\right)$ for use in the replication analysis. Each sample was incubated in the CTAB buffer for 1-1.5 hr in a $60^{\circ} \mathrm{C}$ water bath with occasional mixing. The samples were then stored at room temperature for about $10 \mathrm{~min} .25$ $\mathrm{mL}$ of chloroform/iso-amyl alcohol $(24: 1 \mathrm{v} / \mathrm{v})$ was added to each sample and mixed well, then evacuated. The mixture was then centrifuged at $100 \times \mathrm{g}$ for about $10 \mathrm{~min}$ at room temperature. The aqueous phase (upper phase) was removed with a $25 \mathrm{~mL}$ pipet and placed into a fresh tube. $2 / 3$ volume $(14-16 \mathrm{~mL})$ of cold isopropyl alcohol $\left(-20^{\circ} \mathrm{C}\right)$ was added and mixed gently to precipitate the DNA in each tube. DNA was recovered by one of two methods: (1) If the DNA was flocculate, the sample was centrifuged at $500 \times \mathrm{g}$ for $1-2 \mathrm{~min}$ or $1,600 \times \mathrm{g}$ for $10 \mathrm{~min}$ and the supernatant decanted; or (2) If the precipitate was not obvious, then the sample was centrifuged at $12,000 \times \mathrm{g}$ for $30 \mathrm{~min}$ and carefully decanted. The supernatant was poured off and the tube was reversed on a paper towel to dry until the smell of isopropanol was gone. $10-20 \mathrm{~mL}$ wash buffer was added to each tube, mixed gently and allowed to sit at room temperature for at least $20 \mathrm{~min}$. Each tube was centrifuged at $500 \times \mathrm{g}$ or $1,600 \times \mathrm{g}$ for $10 \mathrm{~min}$ at room temperature. The supernatant was poured off carefully and the pellet was left in the tube to air dry briefly at room temperature. The pellet was resuspended in $1 \mathrm{~mL}$ TE. RNase A was added to a final concentration of 10-100 $\mu \mathrm{g} / \mathrm{mL}(1-10 \mu 1$ of $10 \mathrm{mg} / \mathrm{mL}$ stock) and the tube was incubated for $30 \mathrm{~min}$ at $37^{\circ} \mathrm{C}$. Each sample was diluted with $2 \mathrm{X}$ volume of TE $(2 \mathrm{~mL})$ and then $2.75 \mathrm{X}$ volume of $7.5 \mathrm{M}$ ammonium acetate $(\mathrm{pH} 7.7)(2.3 \mathrm{~mL})$ was added to a final concentration of $2.5 \mathrm{M}$, followed by the addition of $2.5 \mathrm{X}$ volume of cold ethanol $(100 \%)\left(-20^{\circ} \mathrm{C}\right)(2.5 \mathrm{~mL}$ was added). The DNA was centrifuged at $10,000 \times \mathrm{g}$ for $10 \mathrm{~min}$ or 1,600 $\times \mathrm{g}$ for $30 \mathrm{~min}$ in a refrigerated centrifuge $\left(4^{\circ} \mathrm{C}\right)$. The air dried sample was resuspended in an appropriate amount of TE $(\sim 1 \mathrm{~mL})$ and dispensed into $200 \mu \mathrm{l}$ aliquots and stored at $-20^{\circ} \mathrm{C}$. The concentration of template DNA was determined using a UV spectrometer at a wavelength of $260 \mathrm{~nm}$.

Polymerase Chain Reaction Amplification: Twenty primers from two of each Operon kit A and kit B were used.
Forty primers (Table 2 ), ten bases in length, were evaluated for suitability in a pilot survey in which three populations representing different species of Camptotheca were included. These primers were used for the polymerase chain reaction (PCR) based on the protocol of Williams et al., with optimization [16]. Amplification reactions were performed in a volume of $50 \mu \mathrm{L}$ containing $10 \mathrm{mM}$ Tris- $\mathrm{Cl}, \mathrm{pH} 8.3,50$ $\mathrm{mM} \mathrm{KCl}, 2.25 \mathrm{mM} \mathrm{MgCl} 2,0.001 \%$ gelatin, $100 \mu \mathrm{M}$ each of dATP, dCTP, dGTP, and dTTP, 12 picomoles (resuspended in $1 \mathrm{~mL}$ of water, using $0.5 \mu \mathrm{L}$ per reaction) of a single $10-$ base primer, $50 \mathrm{ng}$ of genomic DNA, and 1.0 unit of Taq DNA polymerase (Promega Corp.). All reactions were overlaid with one drop of mineral oil before amplification in the thermocycler.

Amplification was performed in an Amplitron ${ }^{\circledR}$ II (Barnstead I Thermolyne, Dubuque, IA) programmed for preheat $3 \mathrm{~min}$ at $94^{\circ} \mathrm{C}$, followed by 35 cycles of $1 \mathrm{~min}$ at $94^{\circ} \mathrm{C}, 1 \mathrm{~min}$ at $34^{\circ} \mathrm{C}$, and $1 \mathrm{~min}$ and $30 \mathrm{sec}$ at $72^{\circ} \mathrm{C}$, followed by $72^{\circ} \mathrm{C}$ for $5 \mathrm{~min}$. Amplification products were analyzed by electrophoresis in $1.5 \%$ agarose gel and detected by staining with ethidium bromide. A control lacking the DNA template was included in each amplification reaction. The products were viewed under ultraviolet light and photographed using Polaroid 665 film. Also Kodak' Digital Science ${ }^{\mathrm{TM}}$ 1D Image Analysis Software was used to store the images and to analyze the DNA electrophoresis gels for features including mass, molecular weight, intensity measurements and mobility values.

Nomenclature: Each amplified band was named by the primer used and its size in bp. For example, OPA02-2500 refers to the 2,500 bp band amplified by primer OPA02.

Data Analysis: Photographs from ethidium bromide stained agarose gels were used to score the data for RAPD analysis. Starting from the higher molecular weight product to lower molecular weight product, the amplified fragments were designated as described in the nomenclature section. The presence of a product was identified as 1 and its absence was recognized as 0 . In this way, data were scored for all genotypes, their amplification products, and primers. The genetic data obtained was summarized and evaluated using the software package POPGENE [31].

Within populations, two common estimates of genetic variability were computed for each population and then averaged for cultivars, varieties, and species. These estimates included percentage of polymorphic loci $(P)$, which is defined as

$P=$ number of polymorphic loci/total number of loci,

and Shannon's (1949) information index ( $I$ ) for each locus $I$, which is defined as

$$
I_{i}=-\Sigma \pi \log _{2} \pi,
$$

where $\pi$ is the phenotypic frequencies, and averaged across loci:

$$
I=(1 / \mathrm{L}) \times \Sigma I_{i},
$$

where $\mathrm{L}$ is the number of loci.

Total gene diversity $\left(\mathrm{H}_{\mathrm{T}}\right)$, gene diversity within populations $\left(\mathrm{H}_{\mathrm{S}}\right)$, gene diversity among populations $\left(\mathrm{D}_{\mathrm{ST}}\right)$ and the proportion of diversity among populations $\left(\mathrm{G}_{\mathrm{ST}}\right.$, where 
Table 2. Random oligonucleotide primer sequences of Operon Kit A and Kit B.

\begin{tabular}{|c|c|c|c|}
\hline \multicolumn{2}{|c|}{ Kit A } & \multicolumn{2}{|c|}{ Kit B } \\
\hline OPA- 02 & TGCCGAGCTG & OPB-02 & TGATCCCTGG \\
\hline OPA-03 & AGTCAGCCAC & OPB-03 & CATCCCCCTG \\
\hline OPA- 05 & AGGGGTCTTG & OPB-05 & TGCGCCCTTC \\
\hline OPA-06 & GGTCCCTGAC & OPB-06 & TGCTCTGCCC \\
\hline OPA-07 & GAAACGGGTG & OPB-07 & GGTGACGCAG \\
\hline OPA-08 & GTGACGTAGG & OPB-08 & GTCCACACGG \\
\hline OPA-11 & CAATCGCCGT & OPB-11 & GTAGACCCGT \\
\hline OPA-12 & TCGGCGATAG & OPB-12 & CCTTGACGCA \\
\hline OPA-13 & CAGCACCCAC & OPB-13 & TTCCCCCGCT \\
\hline OPA-14 & TCTGTGCTGG & OPB-14 & TCCGCTCTGG \\
\hline OPA-15 & TTCCGAACCC & OPB-15 & GGAGGGTGTT \\
\hline OPA-16 & AGCCAGCGAA & OPB-16 & TTTGCCCGGA \\
\hline OPA-17 & GACCGCTTGT & OPB-17 & AGGGAACGAG \\
\hline
\end{tabular}

$\left.\mathrm{G}_{\mathrm{ST}}=\mathrm{D}_{\mathrm{ST}} / \mathrm{H}_{\mathrm{T}}\right)$ were calculated according to Nei (1973, 1977) $[32,33]$. These statistics were also averaged across all polymorphic loci to obtain species-level and genus-level estimates of genetic diversity.

The number of migrants per generation $(\mathrm{Nm})$ was calculated as the estimate of gene flow from $\mathrm{G}_{\mathrm{ST}}, \mathrm{Nm}=0.5(1-$ $\left.\mathrm{G}_{\mathrm{ST}}\right) / \mathrm{G}_{\mathrm{ST}}$. In other words, the movement of one individual per generation between populations is sufficient to prevent substantial differentiation between those populations. This result, independent of migrants in a population (denoted by $\mathrm{m})$, is counteracted by the force of genetic drift, which is proportional to the inverse of the population size, denoted by $\mathrm{N}$ [34].

Nei's genetic identity (S) and genetic distance (D) were calculated between 25 populations [32]. Nei's genetic distance between populations $\mathrm{X}$ and $\mathrm{Y}$ is defined as

$$
\mathrm{D}=-\ln \left(J_{\mathrm{XY}} / \sqrt{J_{X} J_{Y}}\right),
$$

where $J_{X}, J_{Y}$, and $J_{X Y}$ are the means of $\Sigma x_{i}^{2}, \Sigma y_{i}^{2}$, and $\Sigma x_{i} y_{i}$ over all loci studied, respectively. $x_{i}$ and $y_{i}$ are the frequencies of the $i^{\text {th }}$ allele in populations $\mathrm{X}$ and $\mathrm{Y}$, respectively. Genetic identity is defined as

$$
\mathrm{S}=J_{\mathrm{XY}} / \sqrt{J_{X} J_{Y}}
$$

A dendrogram based on Nei's genetic distance was constructed using the unweighted pair-group arithmetic average (UPGMA) clustering [35].

\section{RESULTS AND DISCUSSION}

\section{Genetic Diversity}

Detailed genetic databases are important in the management of endangered species. The level of genetic variation may influence a population's growth rate and ability to adapt to changing environmental conditions [36].

Primer Selection: Initially the level of polymorphism detected with RAPD markers was assayed in three populations representing different species of Camptotheca. Of the 40 primers screened in this study, three (OPA02, OPA03, and OPA04) were selected because they all revealed multibanded fingerprints, which were clearly scorable. Following primer selection, the above method with selected primers was used in the DNA amplification of all populations and treatments. The number of polymorphic bands for each primer varied from 12 (OPA03) to 16 (OPA02 and OPA04) bands, with an average of 15 bands per primer. The size of the amplified fragments ranged from 268 bp to $4,411 b p$ (Table 3). 
Table 3. List of selected primers and their sequences that produced polymorphic markers among the Camptotheca populations studied.

\begin{tabular}{|c|c|c|}
\hline Primers & $\begin{array}{c}\text { Number of polymorphic } \\
\text { fragments }\end{array}$ & $\begin{array}{c}\text { Size range of the } \\
\text { polymorphic scored } \\
\text { fragments (bp) }\end{array}$ \\
\hline \hline OPA-02 & 16 & $271-3015$ \\
\hline OPA-03 & 12 & $270-2423$ \\
\hline OPA-04 & 16 & $268-4411$ \\
\hline Total/Range & 44 & $268-4411$ \\
\hline
\end{tabular}

Genetic Polymorphism: The RAPD amplification products generated can be classified into two types: constant (monomorphic) and variable (polymorphic) [37]. This difference can be used to examine and establish systematic relationships [38]. Bands were defined as polymorphic if the mean fragment frequency was not fixed (i.e., 1 or 0) [39].

The optimized PCR protocol resulted in highly reproducible banding patterns. A total of 46 strongly amplified and highly reproducible scorable bands were generated using these three selected primers. Among these 46 bands, 44 (95.7\%) were polymorphic and two were monomorphic among all the populations tested according to the allelic frequencies. Allelic frequencies of the 44 polymorphic loci are summarized for each variety and species in Appendix B. Allele frequencies for each population can be obtained from the author. Most of the populations studied possessed unique combinations of bands, thereby permitting their identification. It was noteworthy that the first band of primer OPA03 (OPA03-2423) was present in all individuals of the cultivar 'Katie' (KT) but completely absent in the other populations. The $16^{\text {th }}$ band of primer OPA04 (OPA04-268) was present exclusively in all individuals of the HJ population of $C$. acuminata. The fifth band of primer OPA03 (OPA03-1460) was absent in all individuals of the cultivar 'Ang' (AG) but present in other Camptotheca populations. These distinctive bands can be used to identify these three populations, respectively.

RAPD profiles resulted from the use primers OPA02, OPA03, and OPA04 (Figs. 2-4). The polymorphism revealed in Camptotheca populations by amplification of arbitrary primers is extensive. By using the three primers to analyze diversity within each of 13 populations of $C$. acuminata, nine populations of C. lowreyana, and three populations of C. yunnanensis populations, average estimates of genetic diversity were obtained (Table 4), which provide useful information on population structure at most collection sites.

Data on the number and proportion of polymorphic RAPD loci detected with each primer in the C. acuminata, C. lowreyana, and C. yunnanensis populations are shown in Table 5, with OPA02 and OPA04 detecting the greatest number of scorable polymorphic loci.

The number and proportion of polymorphic loci for each population are also shown in Table 5. KT and G3 populations exhibited the highest level of variability. In contrast, the G9 population exhibited the lowest level of variability with no primer detecting any polymorphic amplification product.

Plant populations under different environmental selection pressures generally show phenotypic differences. Such phenotypic differences may be the result of phenotypic plasticity and/or genetic diversification existing among populations [40].

\section{Genetic Diversity}

Genetic Diversity of the Genus: To assess the overall distribution of variability between and within all populations gene diversity statistics are calculated [33] for each RAPD locus. Gene diversity statistics were presented in Appendix C1. The partitioning of gene diversity within and among populations is reflected in $\mathrm{G}_{\mathrm{ST}}$ values [41]. The total observed diversity estimates $\left(\mathrm{H}_{\mathrm{T}}\right)$ were partitioned into within population diversity $\left(\mathrm{H}_{\mathrm{S}}\right)$ and between population diversity component $\left(\mathrm{D}_{\mathrm{ST}}\right)$, where $\mathrm{H}_{\mathrm{T}}=\mathrm{H}_{\mathrm{S}}+\mathrm{D}_{\mathrm{ST}}$. Gene diversity between populations was expressed relative to total population diversity as $\mathrm{G}_{\mathrm{ST}}=\mathrm{D}_{\mathrm{ST}} / \mathrm{H}_{\mathrm{T}}$.

The distribution of variability differed among polymorphic loci. Total gene diversity $\left(\mathrm{H}_{\mathrm{T}}\right)$ ranged from the lowest value in locus OPA04-4411 (0.0084), detecting the least variability, to the highest values in locus OPA04-880 (0.4982), detecting the most variability. Examination of the gene diversity statistics for each locus indicates an extremely high $\mathrm{G}_{\mathrm{ST}}(1.0000)$ at OPA02-2400, OPA03-2423, OPA03910, and OPA04-268. There was little heterogeneity among loci in patterns of diversity; almost all were characterized by high $\mathrm{G}_{\mathrm{ST}}$ values, suggesting that genetic patterns across loci result from general influences in the entire genome.

An examination of the proportion of diversity present within populations $\left(1-\mathrm{G}_{\mathrm{ST}}\right)$ compared to between populations $\left(\mathrm{G}_{\mathrm{ST}}\right)$ indicated that, on average, more diversity was detected between populations (84.9\%) (Table 5). Most gene diversity is partitioned among rather than within populations, regardless of the differences in absolute levels of diversity (Table 5).

Gene diversity statistics corroborate the pattern of low within-population levels of variation despite high levels of total polymorphism (Table 5). Total gene diversity was high, within-population diversity was low, and most of the genetic diversity occurred between populations. The value of $\mathrm{G}_{\mathrm{ST}}$ obtained for 25 Camptotheca populations was relatively high in relation to other studies [42, 43] using RAPDs. This suggests that at some stage, isolation events have prevented gene flow $(\mathrm{Nm}=0.0889)$ and subsequently, genetic drift has led to considerable population differentiation in Camptotheca.

Species Genetic Diversity: Two common estimates of genetic variability for populations, varieties, and species are listed in Table 6. Camptotheca lowreyana was found to have the highest within-species variability $(\mathrm{P}=63.64$ and $\mathrm{I}=0.2980)$, following by $C$. acuminata $(\mathrm{P}=63.64$ and $\mathrm{I}=0.1753)$, with $C$. yunnanensis, the lowest $(\mathrm{P}=27.27$ and $\mathrm{I}=0.1031$ ). This result is consistent with phenotypic variation analysis. 

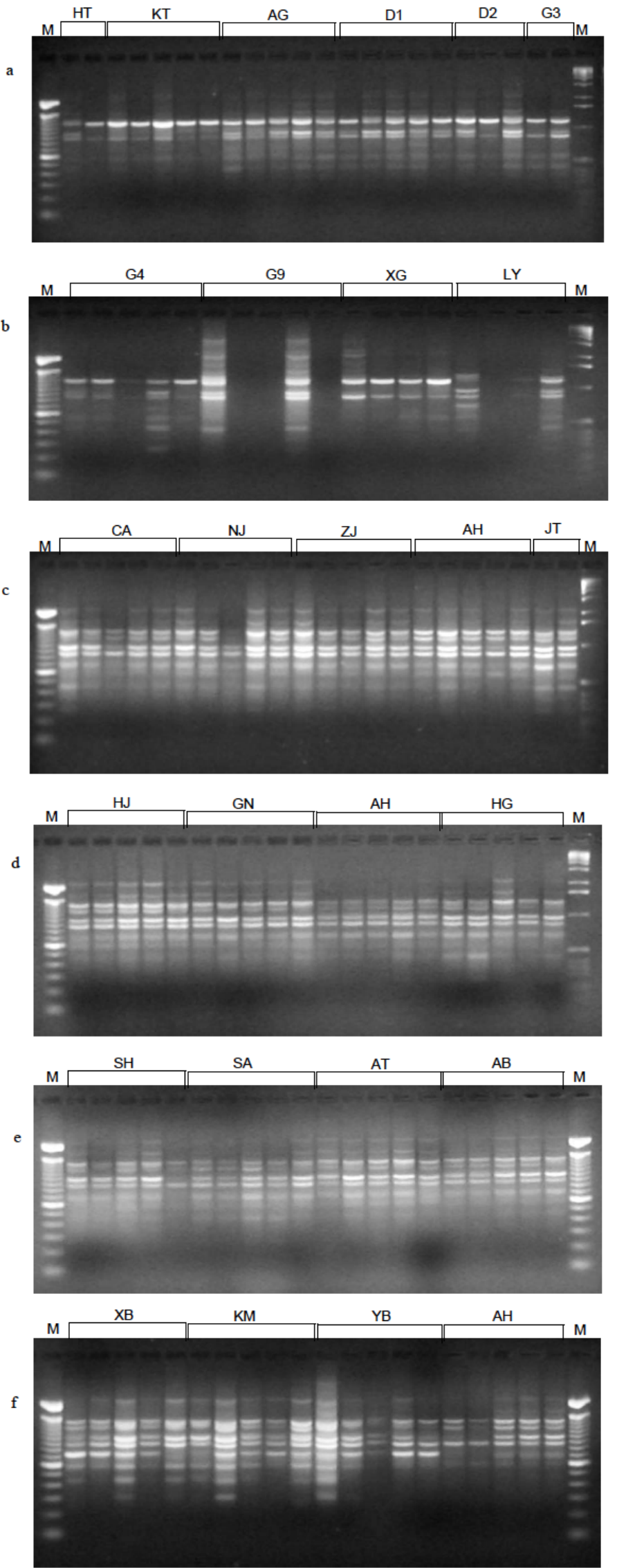

Fig. (2). RAPD profile of 25 populations of Camptotheca using primer OPA02 (a-f). Lane M on the left is a 100 bp ladder marker and on the right is a $1 \mathrm{~Kb}$ or $100 \mathrm{bp}$ ladder marker. 

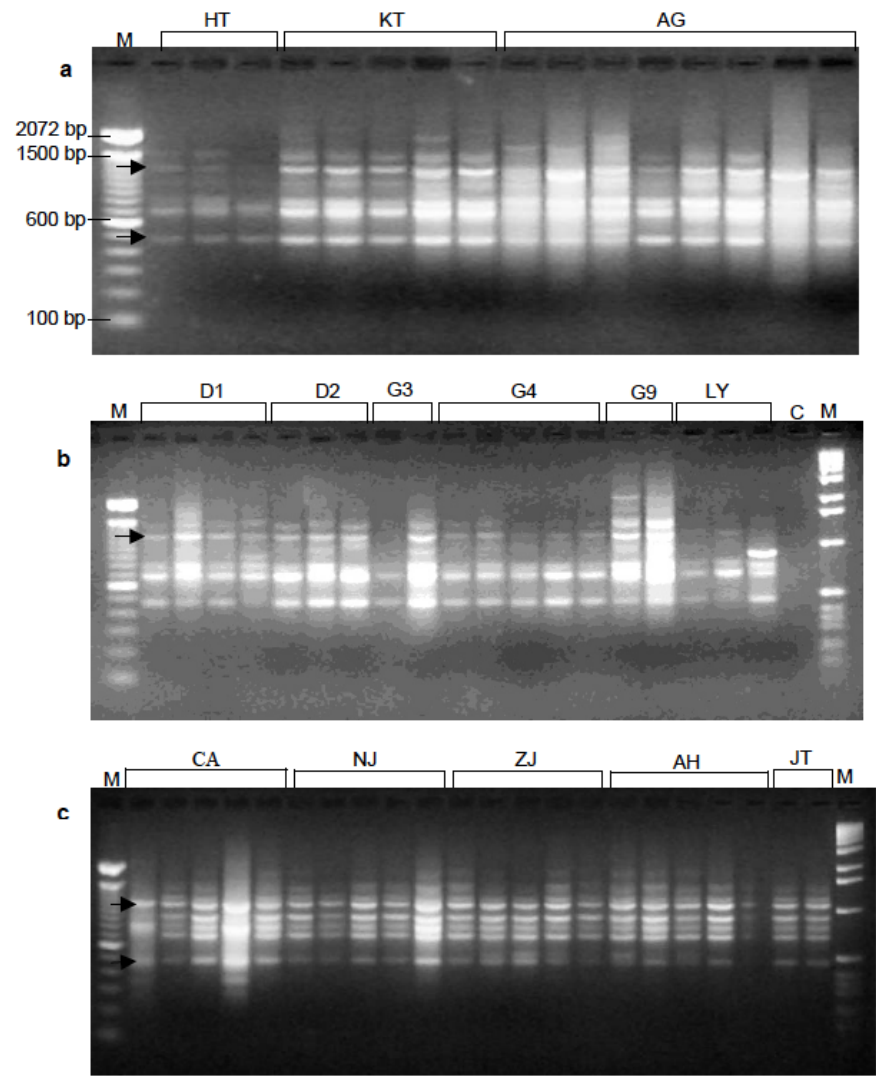

d
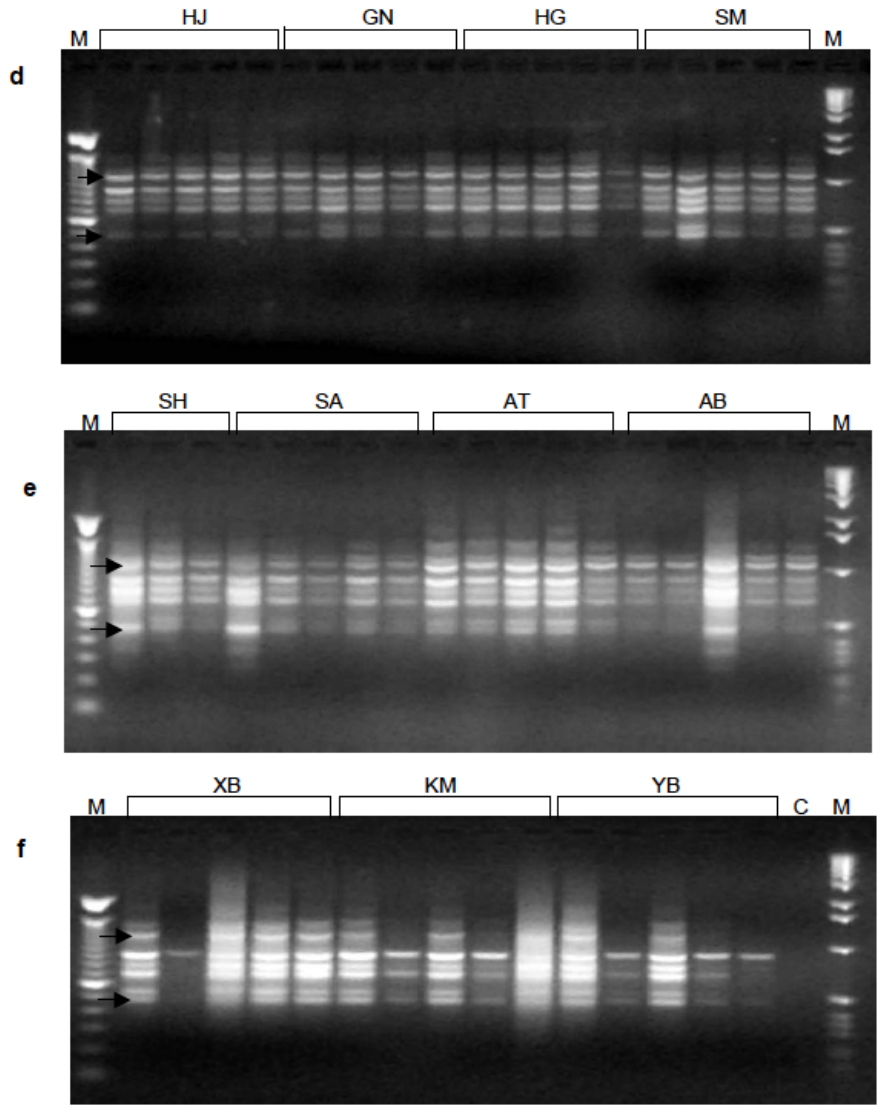

Fig. (3). RAPD profile of 25 populations of Camptotheca using primer OPA03 (a-f). Lane M on the left is a 100 bp ladder marker and on the right is a $1 \mathrm{~Kb}$ ladder marker. Lane $\mathrm{C}$ is a negative control lane without any genomic DNA. The two fragments, OPA03-1100 and OPA03480 , were found in common within all populations (arrows). 

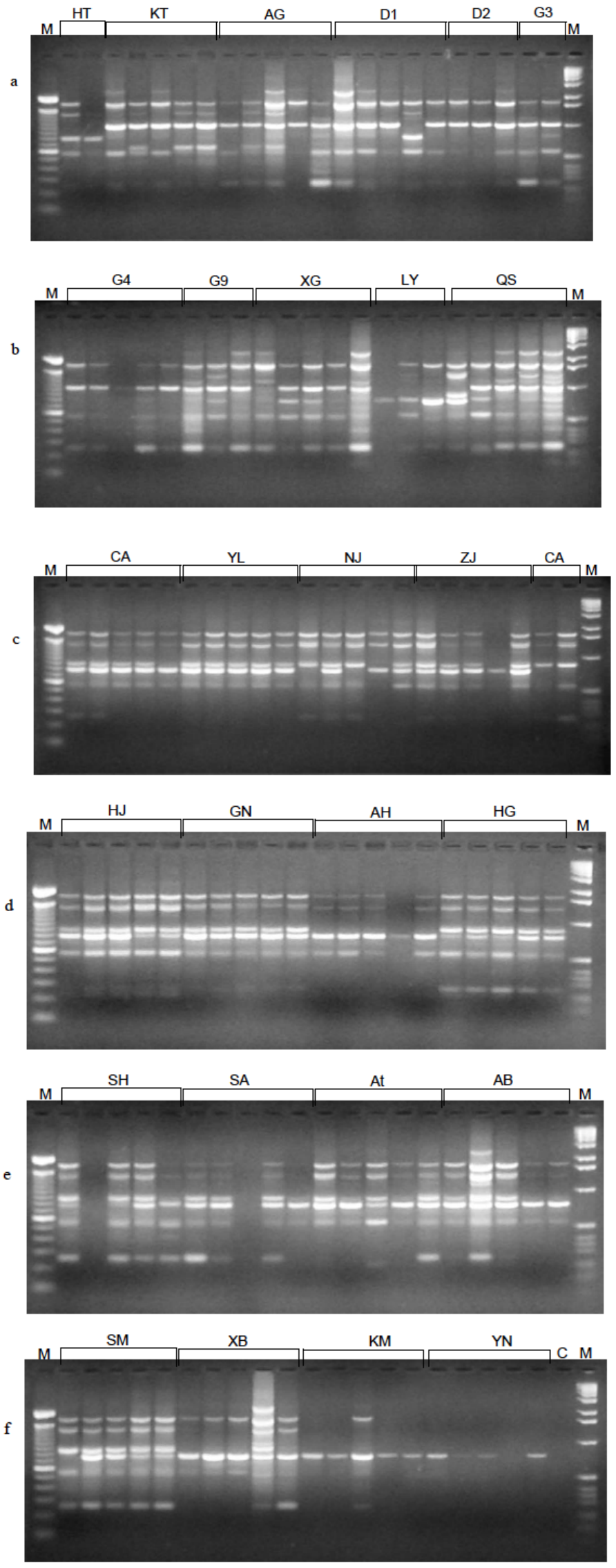

Fig. (4). RAPD profile of 25 populations of Camptotheca using primer OPA04 (a-f). Lane M on the left is a 100 bp ladder marker and on the right is a $1 \mathrm{~Kb}$ ladder marker. Lane $\mathrm{C}$ is a negative control lane without any genomic DNA. 
Table 4. Polymorphic loci detected with three primers for 13 populations of $C$. acuminata, nine of $C$. lowreyana, and three of $C$. yunnanensis and the total number of polymophic loci scored in all the populations (proportion of polymorphic loci).

\begin{tabular}{|c|c|c|c|c|}
\hline Cultivars & \multicolumn{3}{|c|}{$\begin{array}{c}\text { Primer } \\
\text { OPA02 OPA03 OPA04 }\end{array}$} & Total number polymorphic loci \\
\hline HT & $1(0.063)$ & $0(0.000)$ & $0(0.000)$ & $1(0.022)$ \\
\hline KT & $5(0.313)$ & $0(0.000)$ & $3(0.177)$ & $8(0.174)$ \\
\hline AG & $4(0.250)$ & $1(0.071)$ & $2(0.118)$ & $6(0.130)$ \\
\hline D1 & $1(0.063)$ & $2(0.143)$ & $4(0.235)$ & $3(0.065)$ \\
\hline D2 & $3(0.188)$ & $0(0.000)$ & $0(0.000)$ & $3(0.065)$ \\
\hline G3 & $2(0.125)$ & $2(0.143)$ & $4(0.235)$ & $8(0.174)$ \\
\hline G4 & $5(0.313)$ & $1(0.071)$ & $0(0.000)$ & $6(0.130)$ \\
\hline G9 & $0(0.000)$ & $0(0.000)$ & $0(0.000)$ & $0(0.000)$ \\
\hline LY & $4(0.250)$ & $0(0.000)$ & $0(0.000)$ & $4(0.087)$ \\
\hline $\mathrm{CA}$ & $0(0.000)$ & $5(0.357)$ & $0(0.000)$ & $5(0.109)$ \\
\hline NJ & $0(0.000)$ & $3(0.214)$ & $3(0.177)$ & $6(0.130)$ \\
\hline $\mathrm{ZJ}$ & $0(0.000)$ & $2(0.143)$ & $2(0.118)$ & $4(0.087)$ \\
\hline $\mathrm{AH}$ & $0(0.000)$ & $1(0.071)$ & $0(0.000)$ & $1(0.022)$ \\
\hline JT & $0(0.000)$ & $0(0.000)$ & $1(0.059)$ & $1(0.022)$ \\
\hline HJ & $1(0.063)$ & $0(0.000)$ & $1(0.059)$ & $2(0.043)$ \\
\hline GN & $1(0.063)$ & $0(0.000)$ & $0(0.000)$ & $1(0.022)$ \\
\hline HG & $2(0.125)$ & $0(0.000)$ & $0(0.000)$ & $2(0.043)$ \\
\hline SM & $1(0.063)$ & $0(0.000)$ & $3(0.177)$ & $4(0.087)$ \\
\hline $\mathrm{SH}$ & $0(0.000)$ & $3(0.214)$ & $1(0.059)$ & $3(0.065)$ \\
\hline SA & $1(0.063)$ & $2(0.143)$ & $1(0.059)$ & $2(0.043)$ \\
\hline $\mathrm{AT}$ & $1(0.063)$ & $0(0.000)$ & $1(0.059)$ & $1(0.022)$ \\
\hline $\mathrm{AB}$ & $1(0.063)$ & $3(0.214)$ & $6(0.353)$ & $1(0.022)$ \\
\hline $\mathrm{XB}$ & $1(0.063)$ & $0(0.000)$ & $3(0.177)$ & $4(0.087)$ \\
\hline $\mathrm{KM}$ & $1(0.063)$ & $0(0.000)$ & $5(0.294)$ & $6(0.130)$ \\
\hline YB & $5(0.313)$ & $1(0.071)$ & $0(0.000)$ & $6(0.130)$ \\
\hline Total & $16(1.000)$ & $12(0.857)$ & $16(1.000)$ & $44(0.957)$ \\
\hline
\end{tabular}

Table 5. Gene diversity statistics for 25 Camptotheca populations examined with 44 RAPD polymorphic loci detected with three primers.

\begin{tabular}{|c|c|c|c|c|c|}
\hline Species & $\mathbf{H}_{\mathbf{T}}$ & $\mathbf{H}_{\mathbf{S}}$ & $\mathbf{D}_{\text {ST }}$ & $\mathbf{G}_{\text {ST }}$ & $\mathbf{N m}$ \\
\hline \hline C. acuminata & 0.1176 & 0.0249 & 0.0927 & 0.7881 & 0.1344 \\
\hline C. lowreyana & 0.1914 & 0.0429 & 0.1485 & 0.7760 & 0.1444 \\
\hline C. yunnanensis & 0.0647 & 0.0354 & 0.0293 & 0.4529 & 0.8490 \\
\hline Total & 0.2113 & 0.0319 & 0.1794 & 0.0889 \\
\hline
\end{tabular}

Notes: $\mathrm{H}_{\mathrm{T}}$ is total variation in all populations, $\mathrm{H}_{\mathrm{S}}$ is the average gene diversity found within populations, $\mathrm{D}_{\mathrm{ST}}$ is the average gene diversity among populations, $\mathrm{G}_{\mathrm{ST}}$, equivalent to $\mathrm{D}_{\mathrm{ST}} / \mathrm{H}_{\mathrm{T}}$, is the proportion of total gene diversity due to differences among populations, and Nm is the estimate of gene flow from Gst, Nm $=0.5(1-\mathrm{Gst}) / \mathrm{Gst}$. 
For $C$. lowreyana, the highest genetic diversity is found in its natural variety var. lowreyana $(\mathrm{P}=59.09$ and $\mathrm{I}=0.2468)$ (Table 6). This variety also shows greater phenotypic variations among populations. The experimental samples of var. lowreyana represent the different natural populations from Guangdong Province, China. The genetic diversity is much smaller within each cultivar (cultivars 'Hicksii', 'Katie', and 'Ang') because the plants of each cultivar were asexually propagated from their single "parent" plants. The cultivar 'Hicksii' exhibited the lowest diversity $(\mathrm{P}=2.27$ and $\mathrm{I}=0.0137)$. C. lowreyana has not only the highest $\mathrm{H}_{\mathrm{T}}$ value $\left(\mathrm{H}_{\mathrm{T}}=0.1914\right)$ but also a greater proportion of gene diversity distributed among populations $\left(\mathrm{G}_{\mathrm{ST}}=0.7760\right)$ (Table 5).

Table 6. Proportion of polymorphic loci (P) and Shannon's information index (I) for Camptotheca as a whole, each species, variety and cultivar of $C$. acuminata and $C$. lowreyana, and populations within each variety.

\begin{tabular}{|c|c|c|}
\hline Species & $\mathbf{P}$ & $\mathbf{I}$ \\
\hline \hline C. acuminata & 63.64 & 0.1753 \\
var. acuminata & 47.73 & 0.1392 \\
CA & 11.36 & 0.0580 \\
NJ & 13.64 & 0.0774 \\
ZJ & 9.09 & 0.0454 \\
AH & 2.27 & 0.0158 \\
JT & 2.27 & 0.0912 \\
HJ & 4.55 & 0.0271 \\
GN & 2.27 & 0.0121 \\
HG & 4.55 & 0.0243 \\
SM & 9.09 & 0.0520 \\
SH & 6.82 & 0.1412 \\
SA & 4.55 & 0.0315 \\
AT & 2.27 & 0.0156 \\
AB & 22.73 & 0.1102 \\
var. tenuifolia (G9) & 0 & --- \\
\hline C. lowreyana & 63.64 & 0.2980 \\
Var. lowreyana & 59.09 & 0.2468 \\
D1 & 6.82 & 0.0371 \\
D2 & 6.82 & 0.0418 \\
G3 & 18.18 & 0.1099 \\
G4 & 13.64 & 0.0789 \\
LY & 9.09 & 0.0550 \\
'Hicksii' (HT) & 13.64 & 0.0743 \\
C. yatie' (KT) & 2.27 & 0.0137 \\
XB & 18.18 & 0.0948 \\
KM & 27.27 & 0.1031 \\
YB & 9.09 & 0.0406 \\
Total & 13.64 & 0.0549 \\
& 13.64 & 0.0721 \\
\hline & 100.00 & 0.3228 \\
\hline & & \\
\hline
\end{tabular}

Within C. acuminata, var. acuminata exhibited the most variation $(\mathrm{P}=47.73$ and $\mathrm{I}=0.1392)$ (Table 6). Because the other variety, var. tenuifolia, has only one population available for analysis, it is not known how representative of the variant it is. The samples of var. acuminata represent only cultivated plants because no wild population has been identified in its native China to date. Some of these introductions can be traced back to the seed source in China. Therefore, it is reasonable the species has low genetic diversity. For var. acuminata, population $\mathrm{AB}(\mathrm{P}=22.73$ and $\mathrm{I}=0.1102)$ has discernibly more genetic variation. In contrast, the other 12 populations display lower variations $(\mathrm{P}=2.27-11.36) \mathrm{AH}$, JT, GN, and AT have the lowest variations within $C$. acuminata because the seeds of each population originated from a single parent tree. Although it has the lowest genetic diversity, $C$. acuminata has the greatest proportion of gene diversity distributed among populations $\left(\mathrm{G}_{\mathrm{ST}}=0.7881\right)$ (Table 5).

For C. yunnanensis, the difference among three populations was relatively small. The tested materials of $C$. yunnanensis represent the only three known populations in China. Camptotheca yunnanensis not only had the lowest $\mathrm{H}_{\mathrm{T}}$ value $(0.0647)$ but also the lowest proportion of gene diversity distributed among populations $\left(\mathrm{G}_{\mathrm{ST}}=0.4523\right)$ as compared with $C$. acuminata and $C$. lowreyana.

Genetic diversity for all polymorphic loci in each species was estimated. Among polymorphic loci, total genetic diversity $\left(\mathrm{H}_{\mathrm{T}}\right)$ for $C$. lowreyana ranged from 0.0518 (OPA04$1650)$ to the highest values in OPA02-2400 (0.4938) and OPA02-1500 (0.4999).

The $\mathrm{G}_{\mathrm{ST}}$ values of $C$. acuminata and C. lowreyana were relatively higher than the mean value for selfing species. Even the Gst value of $C$. yunnanensis $\left(\mathrm{G}_{\mathrm{ST}}=0.4523\right)$ approached the mean value $\left(\mathrm{G}_{\mathrm{ST}}=0.51\right)$ estimated for selfing species [41]. The higher $\mathrm{G}_{\mathrm{ST}}$ values indicated that, of the total genetic variation, the differences among populations are very significant in each species. The calculated $\mathrm{Nm}$ values, ranging from 0.1344 for C. acuminata to 0.6040 for $C$. yunnanensis, were all less than 1.0, which is commonly taken as the breakpoint below which genetic drift can play a major role in determining the distribution of genetic variation among populational subdivisions [44].

In this study, the level and structure of genetic variation of $C$. acuminata and $C$. lowreyana was described from analysis with RAPD markers. Within-population gene diversity was found to be relatively low compared with other tree species. Population differentiation was found to be higher than other species with similar breeding system. It appeared that fragmentation has caused gene flow to become low enough for factors such as genetic drift and possible inbreeding depression to cause this differentiation. All populations were therefore distinctive genetically and each should be considered as a management unit.

Genetic Identity and Distance: Nei's genetic identity (I) and distance (D) coefficients for all 25 populations of Camptotheca are shown in Appendix D. The mean values for Nei's genetic identity and distance for pairwise combinations of species and populations in Camptotheca are summarized in Table 7. The genetic distance scale runs from 0 (identical) to 1 (different for all criteria studied) and a figure of 0.2824 or more differentiates different species. Exceptions exist between $C$. yunnanensis and C. acuminata $(\mathrm{D}=0.1916)$, and also between $C$. yunnanensis and C. acuminata_var. acuminata $(\mathrm{D}=0.1767)$. Interspecific comparisons indicated that C. yunnanensis was most similar genetically to C. acuminata $(\mathrm{D}=0.1916)$. The highest interspecific identities were 
Table 7. Mean values for Nei's genetic distance for pairwise combinations of species, varieties, and cultivars in Camptotheca.

\begin{tabular}{|c|c|c|c|c|c|c|c|c|c|}
\hline Species/Variety & 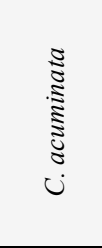 & 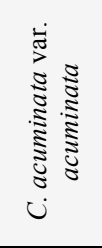 & 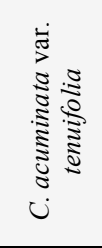 & 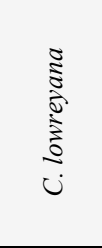 & 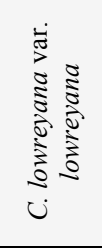 & 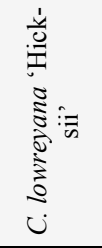 & 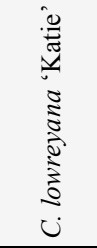 & $\begin{array}{c}0 \\
0 \\
0 \\
0 \\
0 \\
0 \\
0 \\
0 \\
0 \\
0 \\
0 \\
0\end{array}$ & $\begin{array}{l}\vdots \\
\vdots \\
\vdots \\
\vdots \\
\vdots \\
\vdots \\
\vdots \\
ن\end{array}$ \\
\hline C. acuminata & $\underline{0.1078}$ & $\longrightarrow$ & $\longrightarrow$ & 0.3162 & 0.3004 & 0.2431 & 0.3861 & 0.3978 & 0.1916 \\
\hline C. acuminata var. tenuifolia & & & - & 0.3932 & 0.3842 & 0.4021 & 0.4614 & 0.3611 & 0.3862 \\
\hline C. lowreyana & & & & $\underline{0.1973}$ & $\longrightarrow$ & $\longrightarrow$ & $\longrightarrow$ & - & 0.3354 \\
\hline C. lowreyana var. lowreyana & & & & & $\underline{0.1714}$ & 0.1684 & 0.2139 & 0.2353 & 0.3157 \\
\hline C. lowreyana 'Hicksii' & & & & & & $\longrightarrow$ & 0.2323 & 0.2386 & 0.2824 \\
\hline C. yunnanensis & & & & & & & & & $\underline{0.0420}$ \\
\hline
\end{tabular}

Note: Figure underlined is the genetic distance among populations within the taxon.

between C. yunanensis and C. acuminata var. acuminata (D $=0.1767)$. The greatest interspecific distances were between $C$. yunanensis and C. lowreyana 'Ang' $(\mathrm{D}=0.4625)$ and between $C$. acuminata_var. tenuifolia and C. lowreyana 'Katie' $(\mathrm{D}=0.4614)$.

Distance values of 0.1973 or less were obtained within each species and variety, the smallest value arising within $C$. yunnanensis $(\mathrm{D}=0.0420)$, indicating that populations of $C$. yunnanensis were the most similar genetically. The genetic distance value obtained between varieties of $C$. acuminata var. acuminata and var. tenuifolia was higher $(\mathrm{D}=0.4340)$ than most species distances. The genetic distance values obtained between varieties and cultivars of $C$. lowreyana ranged from 0.1684 to 0.2509 . Camptotheca lowreyana var. lowreyana was closer to cultivar 'Hicksii' $(\mathrm{D}=0.1684)$ than to cultivars 'Katie' and 'Ang'. In contrast, the greatest distance existed between cultivars 'Katie' and 'Ang' $(\mathrm{D}=0.2509)$.

The ranges of values obtained between species would suggest that, of all the species studied, C. yunnanensis was the closest relative to $C$. acuminata var. acuminata.

Cluster Analysis: Cluster analysis is a standard method for analyzing the relatedness of individuals (and hence grouping them) from measured data. Cluster analysis has the advantage over some other grouping methods, for example principal component analysis, in that the number of related groups under study does not have to be known, or suspected, in order to carry out the analysis. The main assumption made is that two individuals, or cultivars, which group together at a particular level, share a common ancestor more recently than those that join at a higher level.

Cluster analysis of the genetic distance values was conducted to generate a dendrogram indicating relationships between the Camptotheca populations studied (Fig. 5). The dendrogram generated was in general agreement with Li's taxonomic treatment of Camptotheca [45].
All three species formed distinctive groups, although the $\mathrm{AH}$ population of $C$. acuminata var. acuminata was intermixed with $C$. yunnanensis. Only the G9 population of $C$. acuminata var. tenuifolia formed a distinct group apart from all the other groups. In all analyses, C. acuminata var. acuminata appeared as the closest relative of $C$. yunnanensis, followed at some distance by $C$. lowreyana and, further away, C. acuminata var. tenuifolia.

This result is of significance to Camptotheca breeders currently engaged in the introgression of disease resistances and other useful traits from $C$. yunnanensis into $C$. acuminata var. acuminata. Strong interspecific crossing barriers exist between $C$. lowreyana and $C$. yunnanensis. This is largely because of the geographical isolation of the two species. This is reflected in the genetic distance between them. Thus, C. lowreyana and C. yunnanensis should be separated as a distinct species.

RAPD analysis has some drawbacks, however. The alleles detected are general dominant, meaning that heterozygotes cannot be unambiguously identified during screening. Also, RAPDs will underestimate the amount of genetic variation at some loci because many different alleles can be grouped together in the null class [34].

\section{CONCLUSION}

RAPD markers provide a powerful tool for the identification of some populations (particularly cultivars) and the detection of genetic variation within Camptotheca. The genetic diversity analysis provides a basis for strategy development for both conservation and management of these endangered anticancer trees. Three primers (OPA02, OPA03, and OPA04), generating 44 polymorphic bands, were able to discriminate among 25 Camptotheca_populations. The band size varied from 268-4,411bp, with an average of 15 bands/primer. Of these populations, three can be distinguished by their unique bands, respectively: Cultivar 'Katie' 


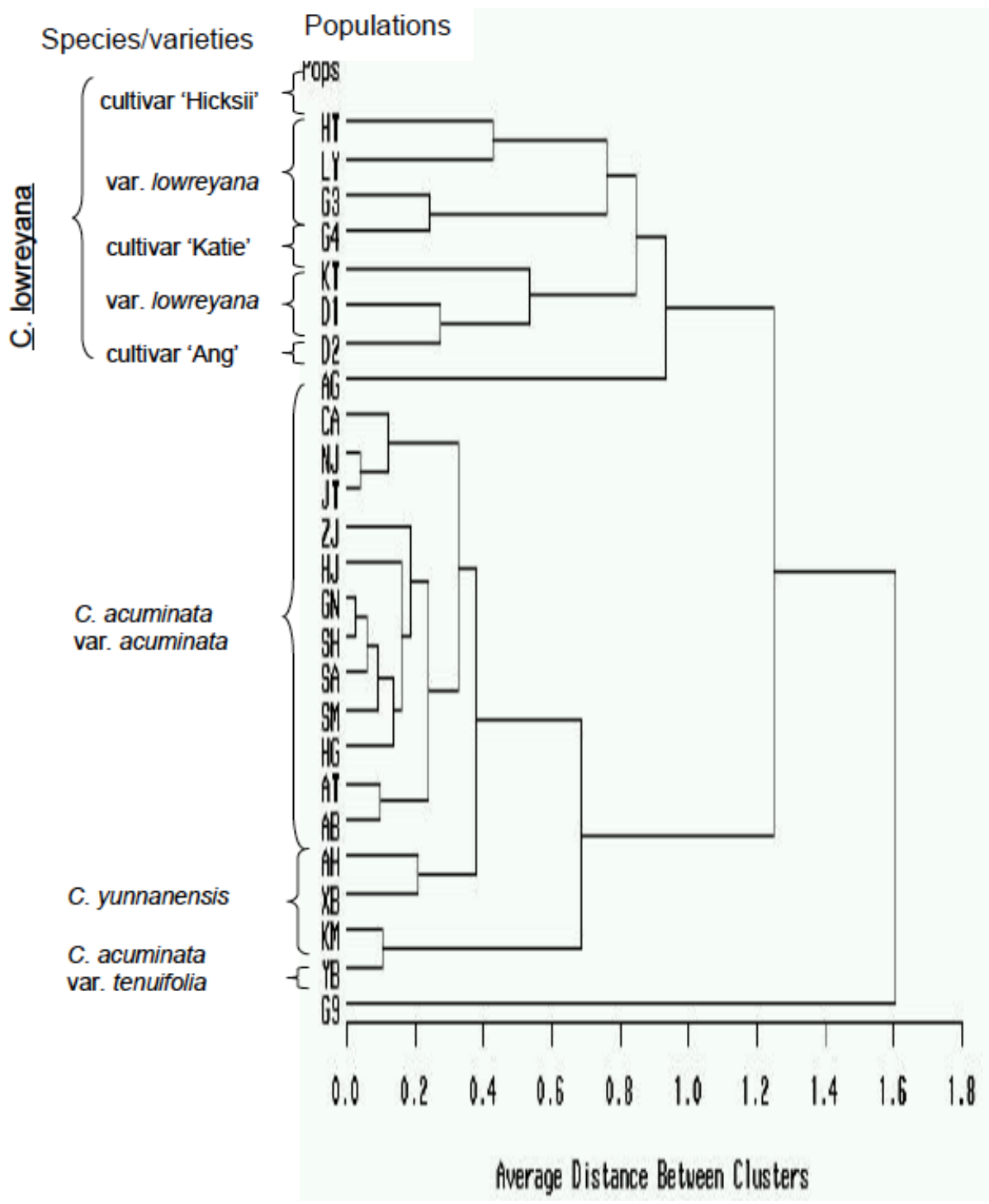

Fig. (5). Dendrogram generated from RAPD DNA markers of 25 populations of Camptotheca.

(KT) (presence of OPA03-2423), the HJ population of $C$. acuminata (presence of OPA04-268), and cultivar 'Ang' (AG) (absence of OPA03-1460).

Camptotheca has relatively low gene diversity within population compared with other tree species. Population differentiation of Camptotheca was found to be higher than in other species with similar breeding systems. It appears that fragmentation has caused gene flow to become low enough for factors such as genetic drift and possible inbreeding depression to cause this differentiation. All populations were therefore distinctive genetically and each should be considered as a management unit. The high level of genetic structure among populations indicates differentiation due to founder events and/or genetic drift coupled with limited migration. Therefore, a conservation approach to conserving these populations is recommended.

Cluster analysis of the genetic distance values and a dendrogram generated from the RAPD markers are consistent with the phenotypic data and both support the current taxonomic treatment of Camptotheca [45]. Camptotheca acuminata var. acuminata appeared as the closest relative of $C$. yunnanensis, followed at some distance by $C$. lowreyana and, further away, C. acuminata var. tenuifolia. Strong interspecific crossing barriers exist between $C$. lowreyana and $C$. yunnanensis due to geographical isolation.

The CPT data of Camptotheca are consistent with the phenotypic and genetic variation analysis. The results show that CPT variation in Camptotheca is mainly determined genetically under the same undisturbed growth conditions. Variation in leaf CPT content of Camptotheca is greater among species than within species. Although it has been widely planted in southern China and many other locations in the world, C. acuminata has relatively low CPT contents and less variation among populations. Considering both low genetic diversity and low CPT yield, the species is not the optimum candidate for plantation development for CPT production. In contract, $C$. lowreyana should be considered as a management target in both CPT production and germplasm conservation because the species not only has higher genetic diversity but also has higher CPT concentrations than the other taxa. 


\section{CONFLICT OF INTEREST}

The authors confirm that this article content has no conflict of interest.

\section{ACKNOWLEDGEMENTS}

Declared none.

\section{PATIENT'S CONSENT}

Declared none.

\section{REFERENCES}

[1] Li, S. Y.; Yi, Y. J.; Wang, Y. J.; Zhang, Z. Z.; Beasley, R. S. Camptothecin accumulation and variation in Camptotheca Decaisne. Planta Med., 2002, 68(11), 1010-1016.

[2] Li, S. Y.; Adair, K. T. Camptotheca acuminata Decaisne, Xi Shu, A Promising Anti-tumor and Anti-viral Tree for the $21^{\text {st }}$ Century. In: Stephen F., Ed. A Henry M. Rockwell Monograph, Texas: Austin State University: Nacogdoches, 1994.

[3] Suzuki, M. Two new species of nyssaceous fossil woods from the palaeogene of Japan. J. Jpn. Bot., 1976, 50, 228-238.

[4] Tanai, T. Fossil leaves of the Nyssaceae from the Miocene of Japan. J. Faculty Sci. Hokkaido Univ. IV. Geol. Mineral., 1977, 17, 505-516.

[5] Manchester, S. R. Cornaceae in Paleocene floras of the Rocky Mountains and Great Plains, Annual Meeting of the Botanical Society of America, Baltimore, Maryland, 2-6 August, 1998.

[6] Chen, L. J.; Wang, F. H.; Wu, Y. R. The pollination biology of Camptotheca acuminata Decne. (Nyssaceae). Cathaya, 1991, 3, 45-52.

[7] Perdue, R. E. Camptotheca acuminata Source of promising cancer drug. Lasca Leaves, 1968, 9, 55-59.

[8] Perdue, R. E.; Smith, R. L.; Wall, M. E.; Hartwell, J. L.; Abbot, B. J. Camptotheca acuminata Decaisne (Nyssaceae) source of camptothecin, an antileukemic alkaloid. Agricultural Research Services, USDA: USA, 1970.

[9] Shao, B. B. Effects of stratification and temperature variation on the germination of seeds of ten different trees. For. Sci. Technol., 1989, 2, 4-7.

[10] Zhou, Y. X. Study on the characteristics of seed dormancy and germination of Camptotheca acuminata. For. Sci. Technol., 1989, $8,22-25$

[11] Jain, A. K.; Nessler, C. L. Clonal propagation of Camptotheca acuminata through shoot bud culture. Plant Cell Tiss. Org. Cult., 1996, 44, 229-233.

[12] Liu, Z. J.; Li, Z. H. Microprpagation of Camptotheca acuminata Decaisne from axillary buds, shoot tips, and seed embryos in a tissue culture system. In Vitro Cell. Dev. Biol., 2001, 37, 84-88.

[13] Chalmers, K. J.; Waugh, R.; Sprent, J. I.; Simons, A. J.; Powell, W. Detection of genetic variation between and within populations of Gliricidia sepium and G. maculata using RAPD markers. Heredity, 1992, 69, 465-472.

[14] Clegg, M. T. Analysis of molecular diversity within and among plant species. In: Development and Application of molecular markers to problems in plant genetics. Current Communications in Molecular Biology, Helebtjaris, T.; Burr, B., Eds.; Cold Spring Harbor Laboratory: New York, 1989; pp. 51-56.

[15] Saiki, R. K.; Gelfond, D. H.; Stoffel, S.; Scharf, S.; Higuchi, R.; Horn, B. T.; Mullis, K. B.; Erlich, H. A. Primer directed enzymatic amplification of DNA with a thermostable DNA polymerase. Science, 1988, 239, 487-491.

[16] Williams, J. G. K.; Kubelik, A. R.; Levak, K. J.; Rafalski, J. A.; Tingey, S. C. DNA polymorphism amplified by arbitray primers as useful as genetic markers. Nucleic Acid Res., 1990, 18, 6531-6535.

[17] Welsh, J.; McCelland, M. Fingerprinting genomes using PCR with arbitrary primers. Nucleic Acid Res., 1990, 18, 7213-7218.
[18] Welsh, J.; Petersen, C.; McClelland, M. Polymorphisms generated by arbitrarily primed PCR in mouse: application to strain identification and genetic mapping. Nucleic Acid Res., 1991, 19, 303-306.

[19] Klein-Lankhorst, R. M.; Vermunt, A.; Weide, R.; Liharska, T. Zabel, P. Isolation of molecular markers for tomato (L. esculentum) using random amplified polymorphic DNA (RAPD). Theor. Appl. Genet., 1991, 83, 108-114.

[20] Wilde, J.; Waugh, R.; Powell, W. Genetic fingerprinting of Theobroma clones using randomly amplified polymorphic DNA markers. Theor. Appl. Genet., 1992, 83, 871-877.

[21] Yang, X.; Quiros, C. Identification and classification of celery cultivars with RAPD markers. Theor. Appl. Genet., 1988, 86, 205212.

[22] Arnold, M. L.; Buckner, C. M.; Robinson, J. J. Pollen-mediated introgression and hybrid speciation in Louisiana irises. Proc. Natl. Acad. Sci. USA, 1991, 88, 1398-1402.

[23] Carlson, J. E.; Tulsieram, L. K.; Glaubitz, J. C.; Luk, V. W. K.; Kauffeldt, C.; Rutledge, R. Segregation of random amplified DNA markers in F1 progeny of conifers. Theor. Appl. Genet., 1991, 83, 194-200.

[24] Kamalay, J. C.; Carey, D. W. Application of RAPD-PCR markers for identification and genetic analysis of American elm (Ulmus americana L.) selections. J. Environ. Hortic., 1995, 13(4), 155159.

[25] Lqbal, M. J.; Paden, D. W.; Rayburn, A. L. Clonal stability of RAPD markers in three Rhododendron species. J. Environ. Hortic., 1995, 13(1), 43-46.

[26] Gawel, N. J.; Johnson, G. R.; Sauve, R. Identification of genetic diversity among Loropetalum chinense var. rubrum introductions J. Environ. Hortic., 1996, 41(1), 38-41.

[27] Brauner, S.; Crawford, D. J.; Stuessey, T. F. Ribosomal DNA and RAPD variation in the rare plant family Lactoridaceae. Am. J. Bot., 1992, 79(12), 1436-1439.

[28] Huff, D. R.; Peakall, R.; Smouse, P. E. RAPD variation within and among natural populations of outcrossing buffalograss $[$ Buchloe dactyloides (Nutt) Enggelm.]. Theor. Appl. Genet., 1993, 86, $927-$ 934.

[29] Chalmers, K. J.; Waugh, R.; Sprent, J. I.; Simons, A. J.; Powell, W. Detection of genetic variation between and within populations of Gliricidia sepium and G. maculata using RAPD markers. Heredity, 1992, 69, 465-472.

[30] Doyle, J. J.; Doyle, J. L. Isolation of plant DNA from fresh tissue. Focus, 1990, 12, 13-15.

[31] Yeh, F. C.; Yang, R. C.; Boyle, T. POPGENE, the user-friendly shareware for population genetic analysis. Molecular Biology and Biotechnology Center, University of Alberta: Canada, 1997.

[32] Nei, M. Genetic distance between populations. Am. Nat., 1972, 106, 283-293.

[33] Nei, M. Analysis of gene diversity in subdivided populations. Proc. Natl. Acad. Sci. USA, 1973, 70, 3321-3323.

[34] McDermott, J. M. Gene flow in plant pathosystems. Ann. Rev. Phytopathol., 1993, 331, 353-373.

[35] Sneath, P. H. A.; Soka, R. R. Numerical Taxonomy. W.M. Freeman and Company: San Fransisco, 1973.

[36] Delany, M. F.; Giesel, J. T.; Brazeau, D. A. Genetic variability among populations of the Florida grasshopper sparrow. J. Wildl. Manag., 2000, 64(3), 631-636.

[37] Orozco-Castillo, C.; Chalmers, K. J.; Waugh, R.; Powell, W. Detection of genetic diversity and selective gene introgression in coffee using RAPD markers. Theor. Appl. Genet., 1994, 87, 934-940.

[38] Hadrys, H.; Balick, M.; Schierwater, B. Genetic and morphological divergence among varieties of Aphanostephus skirrhobasis (Asteraceae-Astereae) and related species with different chromosome numbers. Syst. Bot., 1992, 17(3), 380-394.

[39] Beohm, C. L.; Harrison, H. C.; Jung, G.; Neinhuis, J. Organization of American and Asian Ginseng germplasm using randomly amplified polymorphic DNA (RAPD) markers. J. Am. Hortic. Sci., 1999, 124(3), 252-256

[40] Wen, C. S.; Hsiao, J. Y. Genetic differentiation of Lilium longiflorum Thunb. var. scabrum Masam. (Liliaceae) in Taiwan using random amplified polymorphic DNA and morphological characters. Bot. Bull. Acad. Sin., 1999, 40, 65-71. 
[41] Hamrick, J. L.; Godt, M. J. W. Allozyme diversity in plant species. In: Plant population genetics, breeding and genetic resouces, Brown, A. H. D.; Clegg, M. T.; Kahler, A. L.; Weir, B. S., Eds. Sinauer Associates: Sunderland, Massachusetts, 1989; pp. 43-46.

[42] Rowden, A.; Robertson, A.; Allnutt, T.; Heredia, S.; WilliamsLinera, G.; Newton, C.A. Conservation genetics of Mexican beech, Fagus grandifolia var. mexicana. Conserv. Genet., 2004, 5(4), 475484.
[43] Elisens, W. J.; Boyd, R. D.; Wolfe, A. D. Genetic and morphological divergence among varieties of Aphanostephus skirrhobasis (Asteraceae-Astereae) and related species with different chromosome numbers. Syst. Bot., 1992, 17(3), 380-394.

[44] Wright, S. The genetical structure of populations. Ann. Eugenics, 1951, 15, 313-354

[45] LI, S. Y. Camptotheca lowreyana, a new species of anti-cancer happytrees. Bull. Bot. Res., 1997, 17(3), 348-352.

Received: December 30, 2013

Revised: September 16, 2014

Accepted: September 24, 2014

(C) Wang et al.; Licensee Bentham Open.

This is an open access article licensed under the terms of the Creative Commons Attribution Non-Commercial License (http://creativecommons.org/licenses/by-nc/3.0/) which permits unrestricted, non-commercial use, distribution and reproduction in any medium, provided the work is properly cited. 